Revista Signos

$2010 / 43$

Número Especial

Monográfico $\mathrm{N}^{\circ} 1$
Editorial

\section{Ao número especial Gêneros Textuais/Discursivos e Mídia}

Nas últimas décadas, notadamente a partir dos anos noventa, a problemática dos gêneros textuais/discursivos vem interessando muitos pesquisadores de diferentes países em todos os continentes. É possível assegurar hoje, devido à grande quantidade de pesquisas acerca desse tema, empreendidas sob lentes teórico-metodológicas múltiplas -seja de cunho descritivo-analítico, seja no âmbito da didatização das línguas- que avançamos a passos firmes em direção à consolidação do campo da Linguística dos Gêneros Textuais/Discursivos no cenário da Ciência da Linguagem.

A presente edição da Revista Signos. Estudios de Lingüística reúne trabalhos apresentados no V Simpósio Internacional de Estudos dos Gêneros Textuais, ocorrido em Caxias do Sul, Brasil, de 11 a 14 de agosto de 2009, associados à linha temática 'gêneros e mídia'. Seja do ponto de vista do interacionismo sociodiscursivo, da semiolinguística, da sociorretórica, ou da abordagem sistêmico-funcional, dentre outros quadros teórico-metodológicos, o leitor encontrará aqui uma seleção de doze artigos que tratam dos gêneros de circulação na mídia impressa e digital/internet, com enfoques que se situam nas fronteiras discursivas entre mídia, universidade, ciência, escola, entre outras instâncias. Os artigos que fazem parte desta edição foram selecionados através do processo normal de revisão por pares anônimos do periódico. Isso favoreceu a qualidade desses artigos e garantiu a transparência ao processo de avaliação, que é natural a todos os trabalhos publicados na Revista Signos. Estudios de Lingüística.

0 texto de Alves Filho "Forças centrípetas e forças centrífugas em editoriais”, que abre a coletânea, toma como objeto de estudo editoriais de jornal de empresas jornalísticas diferentes, para investigar as correlações entre integridade e versatilidade genérica. 0 autor utiliza como base do trabalho o pressuposto bakhtiniano da existência de duas forças genéricas (des)reguladoras dos gêneros discursivos: uma de caráter centrípeto, que regula, normatiza, estabiliza, generaliza, promove 
recorrência; outra de caráter centrífugo que desestabiliza, relativiza, dinamiza, 'plasticiza', surpreende.

No artigo "O discurso relatado em textos de divulgação científica midiática constituídos pela relação de solução", Becker e Giering analisam diversos gêneros da divulgação científica, tendo como base a linguística textual, conforme foi definida por Bernárdez (1995) em sua teoria da estrutura retórica. Esse autor realiza uma classificação de processos textuais-retóricos, e é um desses processos (a relação de solução) que as autoras exploram nesse trabalho.

Bezerra, no artigo intitulado "Gêneros digitais: Apresentando livros na Internet”, sob à luz da sociorretórica, investiga, segundo ele próprio, os denominados gêneros introdutórios. 0 autor observa o gênero em sua circulação no ambiente digital, considerando a sua transmutação da mídia impressa para a digital, e a consequente ressignificação no novo suporte.

0 texto "Uma problemática comunicacional dos gêneros discursivos" de Charaudeau, no bojo de sua visada semiodiscursiva, busca encontrar um meio de articular o domínio da prática social com o da atividade discursiva. A proposição do autor consiste precisamente em estruturar o domínio da prática social no domínio da comunicação, demonstrando uma estratégia de análise que parte da situação de comunicação, passa pelas regularidades discursivas, chegando aos aspectos formais da língua. Como ilustração, apresenta sua tese do contrato (discursivo) de comunicação apoiada em discursos propagandísticos, tais como o publicitário, o promocional e o político.

Em "Estructura ilocucionaria y cortesía: La construcción de conocimiento y opinión en las cartas de lectores de ciência", Ciapuscio, com base em um corpus de cartas de leitores da revista Ciência Hoje argentina, identifica e descreve os padrões das estruturas ilocucionárias que caracterizam as cartas polêmicas e, mais especificamente, o trabalho de cortesia realizado por interlocutores para evitar os efeitos indesejáveis dos atos de ameaça à face.

Carvalho, em “O gênero 'crítica’ em dois veículos de mídia digital: Uma análise sob a perspectiva sistêmico-funcional”, demonstra a contribuição da análise de gêneros de orientação sistêmico-funcional para o entendimento da influência do suporte digital na (re)configuração de gêneros que circulam em outros suportes. A autora toma como exemplo os resultados de uma investigação preliminar acerca do gênero Crítica/Resenha, difundida em meio digital no site de duas revistas e em quatro blogs de cinema.

Figueiredo, no artigo "Context, register and genre: Implications for language education", discute a validade dos conceitos de contexto, registro e gênero da linguística sistêmico-funcional para o ensino de línguas. A autora analisa uma carta de leitor publicada na revista Newsweek, 
buscando vislumbrar as possibilidades que se abrem para o ensino de linguagem nessa perspectiva, tendo em conta especialmente o trabalho de Martin (1992, 1997, 2000, 2001).

0 artigo "Livros perigosos para garotos e maravilhosos para meninas: 0 gênero social diferenciando o gênero discursivo", Hessel Silveira analisa dois manuais de auto-ajuda para adolescentes publicados originalmente na Inglaterra. Ela procura mostrar como as representações de gênero social influenciam na configuração do gênero textual/discursivo, uma vez que um dos manuais tem como público ente para meninas e meninos e que: "tais livros [...] estão contribuindo para reafirmar a dicotomia de gênero ainda calcada em binômios tradicionais: sentimento/razão; espaço doméstico/espaço público; sensibilidade/valentia; comunicabilidade/rudeza".

O artigo "O gênero textual 'adaptação oficial de filme em quadrinhos'”, de Lopes Nascimento Saito, traz uma análise de histórias em quadrinhos que consistem em adaptações de filmes já provenientes de histórias em quadrinhos (a exemplo de "O homem-aranha II", foco da análise). A autora se atém aos aspectos verbais e visuais dessas histórias em quadrinhos, utilizando como matriz teórica de sua análise a semiótica de Greimas (1991) e o interacionismo sociodiscursivo de Bronckart (2003).

Menezes, em "Narrativas multimídia de aprendizagem de língua inglesa”, analisa relatos de aprendizagem de língua produzidos alunos do curso de Letras-Inglês da Universidade Federal de Minas Gerais (UFMG). Ela focaliza aspectos relacionados ao gênero e à significação dessas narrativas, a partir de autores da linguística sistêmico-funcional, especialmente Kress e Van Leeuwen (2001, 2006), e da teoria dos espaços mentais de Fauconnier e Turner (2002).

Em "Teoria da relevância e análise sociorretórica de gêneros textuais: Análise de respostas em cartas-consulta diretas e indiretas”, Rauen argumenta que as relações de relevância subjazem à elaboração dos gêneros e podem ajudar a explicá-los. Ele retomou um corpus de cartasconsultas da pesquisa de Simoni (2004) e analisou as diferenças entre as respostas diretas e indiretas que, segundo Simoni, demarcariam dois tipos de carta consulta.

No último artigo desta edição especial da Revista Signos. Estudios de Lingüística, Comunicação multimidiática através do currículo é o tema do artigo "Genre, media, and communicating to learn in the disciplines: Vygotsky developmental theory and North American genre theory", de Russell e Harms. Os autores procuram verificar como o trabalho com diversas mídias e gêneros ajuda no aprendizado da escrita e no desenvolvimento cognitivo de alunos de um curso de engenharia. A partir de duas disciplinas vinculadas, foram produzidos, nos dois primeiros terços do curso ministrado, textos sobre engenharia e agricultura e, no último terço, foram realizados projetos (de divulgação da comunidade de aprendizagem e de montagem de uma competição 
de robôs) no interior dos quais diversos gêneros escritos foram trabalhados. Face ao fato de que essa última etapa do curso se mostrou mais proveitosa, os autores concluem que: "O conteúdo não precisa ser aquele do campo no qual os estudantes estão interessados, desde que eles percebam que esses gêneros fazem parte potencialmente de seu futuro (de sua identidade)".

Esperamos que este número contribua para incrementar o debate em torno dos gêneros midiáticos, favorecendo o avanço dos estudos de gênero mundo afora. Com essa edição especial que junta uma revista do Chile e um evento originado no Brasil, esperamos também renovar os votos de uma integração cada vez maior entre as universidades e os pesquisadores latinoamericanos.

Marcos Baltar

Adair Bonini

Editores Invitados

Número Especial Monogràfico $\mathrm{N}^{\circ} 1$ 